Jurnal Ilmu-Ilmu Peternakan 25 (3): 1-7

ISSN: 0852-3681

E-ISSN: 2443-0765

CFakultas Peternakan UB, http://jiip.ub.ac.id/

\title{
Produksi tepung tongkol jagung muda hasil biodegradasi kapang Pleurotus ostreatus dengan enzim pemecah serat dan implikasinya pada pakan ayam pedaging
}

\author{
Umiani Hatta dan Sugiarto \\ Fakultas Peternakan Universitas Tadulako, Palu, Indonesia, 94118 \\ u_hatta@yahoo.com
}

\begin{abstract}
The purpose of this study was to determine young maize stover flour production resulted from biodegradation Pleurotus ostreatus fungi with fiber digesting enzyme on broiler feed implications. Materials used in this research were young maize stover (60-70 days), Pleurotus ostreatus fungi, urea $\left(\mathrm{CO}-\left(\mathrm{NH}_{2}\right)_{2}\right)$, readily available carbohydrate, aquadest and alcohol. The method used ANOVA test with five treatments and four replication: $\mathrm{R} 0=$ control (without fermentation), $\mathrm{R} 1=10 \mathrm{~g}$ Pleurotus ostreatus $/ \mathrm{kg}$ TTJM; R2 = 20g Pleurotus ostreatus $/ \mathrm{kg}$ TTJM; R3 = 20g Pleurotus ostreatus $/ \mathrm{kg}$ TTJM and R4 $=40 \mathrm{~g}$ Pleurotus ostreatus $/ \mathrm{kg}$ TTJM. The result showed best effect of crude protein $\mathrm{R} 2=32.33$, best effect of crude fat $\mathrm{R} 4=18.59$, best effect of crude fiber $\mathrm{RO}=119.70$, and best effect of energy (kkal) $\mathrm{R} 4=20682.59$. The study concluded that the increasing crude protein and crude fat also decreased crude fiber content as a result of fermentation using Pleurotus ostreatus. The energy content of maize stover had no significant effect due to fermentation.
\end{abstract}

Key words : fermentation, enzyme, maize stover, broiler

\section{PENDAHULUAN}

Pakan merupakan komponen yang membutuhkan biaya besar dalam suatu usaha peternakan. Berbagai upaya yang dilakukan untuk menekan biaya pakan diantaranya adalah pemanfaatan bahan pakan lokal yang dapat menekan biaya produksi karena bahan tersebut tersedia sepanjang tahun dengan harga yang relatif lebih murah. Bahan pakan lokal yang potensial digunakan sebagai pakan antara lain dedak padi, bungkil inti sawit, lumpur sawit, bungkil kelapa, dan limbah industri pertanian lainnya seperti tongkol jagung muda.

Tongkol jagung muda sudah banyak digunakan sebagai bahan pakan ternak ruminansia tetapi belum lazim digunakan sebagai bahan pakan unggas disebabkan kandungan serat dan asam fitat yang relatif tinggi. Jika tepung tongkol jagung dapat digunakan lebih banyak dalam ransum maka akan mampu menurunkan biaya produksi karena tongkol jagung muda hampir tidak memiliki nilai ekonomis. Unggas tidak memproduksi enzim pemecah serat dan fitase sehingga harus ditambahkan kedalam ransum, sehingga perlu dilakukan biodegradasi melalui fermentasi untuk mendegradasi kandungan serat yang tinggi.

Fermentasi yang digunakan dalam penelitian ini diproduksi dengan teknologi fermentasi media padat (SSF). Teknologi fermentasi dapat 
meningkatkan mutu bahan pakan dan secara umum semua produk akhir fermentasi mengandung senyawa yang lebih sederhana dan mudah dicerna daripada bahan asal sehingga dapat meningkatkan kandungan nutrien bahan (Sari dan Purwadaria, 2004; Sinurat dkk., 1998; Supriyati dkk., 1998). Mikroba yang digunakan dari golongan jamur karena mampu memproduksi berbagai jenis enzim yang berbeda (Mc Cleary, 1988). Selain itu, Ikram et al (2005) menambahkan bahwa jamur adalah mikroorganisme utama yang dapat memproduksi selulase.

Biodegradasi tongkol jagung muda melalui fermentasi diharapkan akan memberi nilai tambah pada limbah tongkol jagung muda. Oleh karena itu Penelitian ini bertujuan untuk mendapatkan kandungan nutrien tepung tongkol jagung muda (TTJM) dan tepung tongkol jagung muda fermentasi (TTJMF) dengan suplementasi 2,5\% N.

\section{MATERI DAN METODE}

Penelitian ini dilaksanakan pada bulan April sampai Oktober 2015.di Laboratorium Nutrisi dan Makanan Ternak Fakultas Peternakan Universitas Brawijaya.

Bahan yang digunakan dalam penelitian ini adalah tongkol jagung muda umur 60-70 hari yang diperoleh dari limbah pasar (penjual jagung), kapang Pleurotus ostreatus, Urea (CO$\left.\left(\mathrm{NH}_{2}\right)_{2}\right)$ sebagai sumber N. Sumber karbohidrat siap pakai (readily available carbohydrate) yang digunakan pada proses fermentasi adalah jagung, akuades dan alkohol. Peralatan yang digunakan adalah talang fermentasi, plastik autoklaf, autoklaf, timbangan, gelas ukur, baskom pencampuran, talang pendinginan, peralatan analisis proksimat dan bom kalorimeter.
Percobaan dilakukan dengan metode eksperimen menggunakan Rancangan Acak Lengkap dengan 5 perlakuan dan setiap perlakuan diulang sebanyak 3 kali. Perlakuan yang dicobakan adalah sebagai berikut :

$\mathrm{R} 0=$ kontrol (tanpa fermentasi)

$\mathrm{R} 1=10 \mathrm{~g}$ Pleurotus ostreatus $/ \mathrm{kg}$ TTJM

$\mathrm{R} 2=20 \mathrm{~g}$ Pleurotus ostreatus $/ \mathrm{kg}$ TTJM

R3 = 20 g Pleurotus ostreatus $/ \mathrm{kg}$ TTJM

$\mathrm{R} 4=40 \mathrm{~g}$ Pleurotus ostreatus $/ \mathrm{kg}$ TTJM

Jumlah Urea $\left(\mathrm{CO}-\left(\mathrm{NH}_{2}\right)_{2}\right)$ yang ditambahkan untuk semua perlakuan adalah 2,5\% dari berat bahan kering substrat tongkol jagung setiap perlakuan. Jagung sebagai sumber $\mathrm{KH}$ yang ditambahkan untuk semua perlakuan adalah 2,5\% dari berat bahan kering substrat tongkol jagung setiap perlakuan.

Peubah yang diamati untuk melihat respon terhadap perlakuan yang diberikan adalah kandungan protein kasar, lemak kasar, serat kasar dan Bahan Ekstrak Tanpa Nitrogen (BETN) dan gross energi yang diukur menggunakan metode analisa kimia (AOAC, 1990). Data yang diperoleh diolah menggunakan analisis sidik ragam dilanjutkan dengan uji Jarak Berganda Duncan (Steel dan Torrie, 1992).

\section{HASIL DAN PEMBAHASAN}

\section{Pengaruh perlakuan terhadap kandungan protein kasar}

Uji statistik menggunakan sidik ragam dilakukan untuk mengetahui pengaruh perlakuan terhadap kandungan protein kasar. Hasil penenlitian menunjukkan bahwa tidak terjadi perbedaan yang nyata terhadap peningkatan kandungan protein kasar 
tongkol jagung hasil biodegradasi kapang Pleurotus ostreatus. Namun ada kecenderungan kandungan protein tertinggi terlihat pada perlakuan R2 dengan level kapang Pleurotus ostreatus sebesar 20\%, selanjutnya dikuti oleh R3 level 30\% dan R4 level
$40 \%$ masing-masing sebesar 8,08; 7,85 dan $7,64 \%$. Kisaran kandungan protein kasar tongkol jagung muda sebelum dan sesudah biodegradasi menggunakan kapang Pleurotus ostreatus dapat dilihat pada Tabel 1.

Tabel 1. Rataan kandungan protein kasar tongkol jagung hasil biodegradasi menggunakan kapang Pleurotus ostreatus

\begin{tabular}{ccccccc}
\hline \multirow{2}{*}{ Ulangan } & \multicolumn{7}{c}{ Perlakuan (\%) } \\
\cline { 2 - 7 } & R0 & R1 & R2 & R3 & R4 & Total \\
\hline 1 & 4.70 & 7.49 & 8.22 & 7.53 & 7.63 & 35.57 \\
2 & 4.25 & 6.19 & 8.25 & 7.27 & 7.94 & 33.90 \\
3 & 3.95 & 6.08 & 7.61 & 8.14 & 7.82 & 33.60 \\
4 & 4.42 & 6.25 & 8.25 & 8.45 & 7.15 & 34.52 \\
\hline Jumlah & 17.32 & 26.01 & 32.33 & 31.39 & 30.54 & 137.59 \\
Rataan & $4.33^{\mathrm{a}}$ & $6.50^{\mathrm{a}}$ & $8.08^{\mathrm{a}}$ & $7.85^{\mathrm{a}}$ & $7.64^{\mathrm{a}}$ & \\
\hline
\end{tabular}

Keterangan : Superscript yang sama pada kolom dan baris menunjukkan hasil tidak berbeda nyata

Hasil penelitian menunjukkan bahwa tidak nampaknya peningkatan protein kasar yang nyata disebabkan karena kandungan protein kasar tongkol jagung muda sebagai substrak fermentasi sangat rendah. Hatta et al. (2014) menyatakan bahwa sumber protein hanya diperoleh dari substrat. Hasil penelitian juga menunjukkan bahwa terdapat kecenderungan peningkatan protein pada level 20, 30 dan $40 \%$ dibandingkan dengan tanpa fermentasi dan level $10 \%$ sebagai akibat adanya suplementasi nitrogen dalam bentuk urea yang ditambahkan pada saat fermentasi dilakukan dimana kandungan nitrogen pada urea yang digunakan cukup tinggi (sekitar 46,60\%), sehingga perlakuan suplementasi urea sebanyak $10 \%$ sebagai sumber nitrogen dapat menghasilkan kandungan proitein kasar yang lebih besar dibandingkan sebelum fermentasi. Dibandingkan dengan kandungan protein kasar tongkol jagung tanpa perlakuan $(4,33 \%)$, kandungan protein kasar pada tongkol jagung hasil biodegradasi menggunakan kapang Pleurotus ostreatus dengan penambahan urea mengalami peningkatan 2 kali lebih besar.

Peningkatan protein kasar pada tongkol jagung muda hasil fermentasi juga dapat terjadi akibat adanya pertumbuhan dan perkembangbiakan kapang selama proses fermentasi. Secara umum semua produk akhir fermentasi biasanya mengandung senyawa yang lebih sederhana dan mudah dicerna daripada bahan asal sehingga dapat meningkatkan nilai gizi bahan. Berbagai jenis mikroorganisme mempunyai kemampuan untuk mengkonversi pati menjadi protein dengan penambahan nitrogen anorganik melalui fermentasi.

\section{Pengaruh perlakuan terhadap kandungan lemak kasar}

Kandungan lemak kasar pada tongkol jagung hasil biodegradasi 
Tabel 2. Rataan kandungan lemak kasar tongkol jagung muda hasil biodegradasi menggunakan kapang Pleurotus ostreatus

\begin{tabular}{ccccccc}
\hline \multirow{2}{*}{ Ulangan } & \multicolumn{7}{c}{ Perlakuan (\%) } \\
\cline { 2 - 7 } & R0 & R1 & R2 & R3 & R4 & Total \\
\hline 1 & 3.40 & 3.23 & 3.63 & 4.61 & 4.81 & 19.68 \\
2 & 3.42 & 3.45 & 4.25 & 3.39 & 4.67 & 19.18 \\
3 & 3.25 & 3.35 & 3.60 & 4.43 & 4.66 & 19.29 \\
4 & 3.25 & 3.35 & 3.75 & 4.25 & 4.45 & 19.05 \\
\hline Jumlah & 13.32 & 13.38 & 15.23 & 16.68 & 18.59 & 77.20 \\
Rataan & $3.33^{\mathrm{a}}$ & $3.35^{\mathrm{a}}$ & $3.81^{\mathrm{b}}$ & $4.17^{\mathrm{b}}$ & $4.65^{\mathrm{b}}$ & \\
\hline
\end{tabular}

Keterangan : Superscript yang sama pada kolom dan baris menunjukkan hasil tidak berbeda nyata

Peningkatan penambahan level Pleurotus ostreatus pada Tabel 2 menunjukkan peningkatan kandungan lemak kasar yang berbeda sangat nyata. Kandungan lemak kasar mencapai angka tertinggi pada R2, R3 dan R4 masing-masing sebesar sebesar 3,81; 4,17 dan 4,65\% dibandingkan dengan kandungan lemak kasar pada tongkol jagung tanpa pengolahan dengan biodegradasi dan pada level $10 \%$ yakni masing-masing sebesar 3,33 dan 3,35\%. Hasil yang diperoleh pada parameter kandungan lemak ini sesuai dengan hasil penelitian Noverina, dkk (2008) yang menggunakan kapang Pleurotus ostreatus pada tongkol jagung yakni sebesar 4,64\%. Hal ini diduga terjadi karena pertumbuhan kapang Pleurotus ostreatus pada level 20, 30 dan 40\% mencapai pertumbuhan maksimal sehingga memberikan sumbangan terhadap peningkatan kandungan lemak kasar produk fermentasinya. Noverina, dkk (2008) lebih lanjut menguraikan bahwa proses fermentasi dapat menimbulkan perubahan fisik dan kimia dari senyawa organik substrat akibat aktifitas mikroba. Lebih lanjut dikemukakan bahwa mikroba juga dapat digunakan untuk memproduksi senyawa kimia tertentu atau mengubah substansi asal menjadi substansi lain yang dikehendaki. Menurut Shurtleff dan Aoyagi (1979), perubahan yang terjadi selama proses fermentasi berlangsung dapat terjadi pada lemak dalam substrat. Lemak netral akan terhidrolisis menjadi asam lemak bebas dan yang terbanyak dihasilkan adalah asam linoleat dimana sebanyak $40 \%$ akan digunakan untuk pertumbuhan jamur.

\section{Pengaruh perlakuan terhadap kandungan serat kasar}

Biodegradasi tongkol jagung muda menggunakan kapang Pleurotus ostreatus menghasilkan kandungan serat kasar yang bervariasi dengan kisaran antara 9,28\% sampai 27,08\%. Analisis sidik ragam memberikan pengaruh berbeda nyata terhadap penurunan kandungan serat kasar tongkol jagung hasil biodegradasi. Hasil ini menunjukkan bahwa proses fermentasi tongkol jagung oleh kapang Pleurotus ostreatus pada level 10-40\% menunjukkan perubahan komponen serat kasar tongkol jagung sebagai substrat pada proses fermentasi tersebut. Enzim-enzim yang dihasilkan oleh jamur tiram (Pleurotus Ostreatus) yaitu fenol oksidase yang terdiri dari 
enzim peroksidase dan lakase, serta enzim aril alkohol oksidase (AAO/ tirosinase) yang mampu mendegradasi lignoselulosa (Ghunu dan Tarmidi, 2006). Rataan kandungan serat kasar dapat dilihat pada Tabel 3 .

Tabel 3. Rataan kandungan serat kasar tongkol jagung hasil biodegradasi menggunakan kapang Pleurotus ostreatus (\%).

\begin{tabular}{ccccccc}
\hline \multirow{2}{*}{ Ulangan } & \multicolumn{7}{c}{ Perlakuan (\%) } \\
\cline { 2 - 7 } & R0 & R1 & R2 & R3 & R4 & Total \\
\hline 1 & 30.11 & 28.71 & 17.33 & 15.45 & 9.51 & 101.11 \\
2 & 29.10 & 24.55 & 19.35 & 13.25 & 8.79 & 95.04 \\
3 & 31.25 & 26.69 & 20.27 & 14.82 & 8.71 & 101.74 \\
4 & 29.24 & 28.35 & 20.18 & 15.43 & 10.12 & 103.32 \\
\hline Jumlah & 119.70 & 108.30 & 77.13 & 58.95 & 37.13 & 401.21 \\
Rataan & $29.93^{\text {e }}$ & $27.08^{\mathrm{d}}$ & $19.28^{\mathrm{c}}$ & $14.74^{\mathrm{b}}$ & $9.28^{\mathrm{a}}$ & \\
\hline
\end{tabular}

Keterangan : Superscript yang sama pada kolom dan baris yang sama menunjukkan hasil tidak berbeda nyata

Kandungan serat kasar tongkol jagung hasil biodegradasi menggunakan kapang Pleurotus Ostreatus paling rendah ditunjukkan pada perlakuan R4 (level $40 \%$ ) yakni sebesar 9,28\%. Jika dibandingkan dengan angka tertinggi kandungan serat kasar pada perlakuan R0 (tanpa fermentasi) dan R1 (level $10 \%$ ) masing-masing sebesar sebesar 29,93 dan $27,08 \%$, maka telah terjadi penurunan yang cukup besar, yaitu sekitar 21\%. Penurunan kandungan serat kasar ini terjadi karena adanya proses fermentasi oleh kapang Pleurotus Ostreatus. Menurut Basuki dan Wiryasasmita (1987) dan Irawadi (1991), proses fermentasi akan mengakibatkan terjadinya pemecahan ikatan kompleks lignoselulosa menjadi ikatan yang lebih sederhana dalam bentuk selulosa sehingga selulosa mudah dipecah oleh enzim selulase yang dihasilkan oleh mikroba. Menurut Cain (1980), serat kasar merupakan komponen utama yang banyak mengandung karbohidrat struktural sumber energi bagi jamur disamping bahan ekstrak tanpa nitrogen (BETN), sehingga sebagian fraksi serat kasar digunakan sebagai sumber energi bagi pertumbuhan kapang Neurospora sitophila terutama untuk pertumbuhan misellium dengan cara mendegradasi serat kasar menggunakan kerja enzim selulase yang dihasilkannya. Akibatnya terjadi penurunan kandungan serat kasar pada substrat yang digunakan sebagai media fermentasi.

\section{Pengaruh perlakuan terhadap kandungan energi}

Kandungan energi tongkol jagung hasil biodegradasi menggunakan kapang Pleurotus ostreatus bervariasi antara 5027.98 kkal sampai dengan 5170.65 kkal. Hasil uji sidik ragam menunjukkan pengaruh perlakuan tidak berbeda nyata terhadap kandungan energi. Data rataan kandungan energi tongkol disajikan pada Tabel 4. 
Tabel 4. Rataan kandungan energi tongkol jagung hasil biodegradasi menggunakan kapang Pleurotus ostreatus (kkal)

\begin{tabular}{ccccccc}
\hline \multirow{2}{*}{ Ulangan } & R0 & R1 & R2 & R3 & R4 & Total \\
\cline { 2 - 7 } & 5126.59 & 5122.34 & 5046.86 & 4949.25 & 5147.97 & 25393.01 \\
1 & 4950.24 & 5121.12 & 5112.22 & 5222.47 & 5112.77 & 25518.82 \\
3 & 5009.85 & 4950.15 & 5080.12 & 5079.55 & 5219.40 & 25339.07 \\
4 & 5025.25 & 5050.25 & 5115.15 & 5210.10 & 5202.45 & 25603.20 \\
\hline Jumlah & 20111.93 & 20243.86 & 20354.35 & 20461.37 & 20682.59 & 101854.10 \\
Rataan & 5027.98 & 5060.97 & 5088.59 & 5115.34 & 5170.65 & \\
\hline
\end{tabular}

Keterangan : Superscript yang sama pada kolom dan baris yang sama menunjukkan hasil tidak berbeda nyata

Kandungan energi yang dicapai pada perlakuan semua level kapang Pleurotus ostreatus secara statistik sama. Fenomena ini terjadi karena imbangan substrak tongkol jagung dengan level kapang yang akan mendegradasi semua komponen pembentuk energi tongkol jagung belum maksimal. Hal ini terjadi diantaranya karena kandungan serat tongkol jagung cukup tinggi yakni 29,10 hingga 31,25 (Hatta, 2014). Level kapang Pleurotus ostreatus yang digunakan belum mampu menghasilkan enzim dalam jumlah yang cukup banyak untuk merombak serat kasar dalam substrat menjadi molekul yang lebih sederhana sebagai komponen energi dalam substrat.

Enzim selulase yang diekskresikan kapang Pleurotus ostreatus belum mampu melakukan degradasi terhadap fraksi serat kasar menjadi molekul sederhana dalam bentuk monosakarida sehingga kandungan energi dalam substrat tetap. Pamungkas et al. (2006) menggunakan Pleurotus flabelatus yang merupakan jamur pembusuk putih (white rot fungi) untuk fermentasi jerami jagung. Jamur ini dapat mengeluarkan enzim-enzim pemecah selulosa dan lignin sehingga kecernaan bahan kering jerami jagung akan meningkat.

\section{KESIMPULAN DAN SARAN}

Hasil penelitian menyimpulkan bahwa terjadi peningkatan kandungan protein kasar dan lemak kasar serta penurunan kandungan serat kasar akibat fermentasi menggunakan Pleurotus ostreatus. Namun, kandungan energi tongkol jagung tidak berpengaruh nyata akibat fermentasi.

\section{DAFTAR PUSTAKA}

AOAC. 1990. Association of official analitical chemist official methods of analyses. Third Edition. AOAC. Washington DC.

Basuki, T dan R. Wiryasasmita. 1987. Improvement of the nutritive value of straw by biological treatment. Dalam: Limbah pertanian sebagai pakan dan manfaat lainnya. M. Soejono., A. Musofie, R. Utomo., N.K. Wardhani, J. B. Schiere (Ed). Proceeding Biocovertion Project Second Workshop on Crop Residue for Feed and Another Purpose, Grati.

Cain, R. B. 1980. The uptake and catabolism of lignin related aromatic compounds and their regulation in microorganism. In T. K. Kirk, T. Higuchi and $\mathrm{H}$. 
Chang (Eds). Lignin Biodegradation: Microbiology, Chemystry and Potential Applications. Volume I. CRC Press, Inc. Boca Raton. Florida. $21-56$.

Ghunu, S dan Tarmidi, A. R. 2006. Perubahan komponen serat Rumput Kume (Sorghum plumosum var. Timorense) hasil biokonversi Jamur Tiram Putih (Pleurotus ostreatus) akibat kadar air substrat dan dosis inokulum yang berbeda. Jurnal Ilmu Ternak Volume. 6 No.2 Hal: $81-86$.

Hatta. U, O Sjofjan, I Subagiyo and B Sundu. 2014. Effects of fermentation by Trichoderma viride on nutritive value of copra meal, cellulase activity and performance of broiler chickens. Livestock Research for Rural Development, Volume 26, Number 4, April 2014.

Ikram-ul-haq, Muhammad Mohsin Javed, Tehmina Saleem Khan and Zafar Siddiq. 2005. Cotton saccharifying activity of cellulases produced by coculture of Aspergillus.

Irawadi, T. T. 1991. Produksi enzim ekstraseluler (Selulase dan Xilanase) dari Neurospora $s p$ pada substrat limbah padat kelapa sawit. Disertasi. IPB. Bogor.

Mc Cleary, B.V. 1988. Synthetis of betaD-mannopyranosides for the assay of beta $\mathrm{N}$-mannosidase and exo beta D-mannanase. Methods in enzymology, 160: 515-518.

Noverina. N., Harlina. T, Yolandasari. D, Septianie. A, Nugraha. K, Dhalika. T, Budiman. A dan Mansyur. 2008. Evaluasi nilai nutrisi tongkol jagung hasil bioproses kapang Neurospora sitophila dengan suplementasi Sulpur dan Nitrogen. Jurmal Ilmu Ternak, Juni 2008, VOL. 8, NO. $1,35-42$.

Pamungkas, D., Romjali. E dan Angraeny. Y. N. 2006. Peningkatan mutu biomas jagung menunjang penyediaan pakan sapi potong sepanjang tahun. Pros. Lokakarya Nasional Jejaring Pengembangan Sistem Integrasi Jagung - Sapi. Pontianak, 9 - 10 Agustus 2006. Puslitbang Peternakan, Bogor. hlm. $142-148$.

Sari L dan Purwadaria T. 2004. Pengkajian nilai gizi hasil fermentasi mutan Aspergillus niger pada substrat bungkil kopra dan bungkil inti sawit. Biodiversitas 2 (5) : 48-51.

Shurtleff W and A. Aoyagi. 1979. The Microbiology and chemystry of tempeh fermentation. The Book of Tempeh, Profesional Addition. Harper and Row Publisher, New York.

Sinurat, A. P., T. Purwadaria, A. Habibie, T. Pasaribu, H. Hamid, J. Rosida, T. Haryati dan I. Sutikno. 1998. Nilai gizi bungkil kopra terfermentasi dalam pakan itik petelur dengan kadar fosfor yang berbeda. Jurnal Ilmu Ternak dan Veteriner 3 (1): 1521.

Steel R. G. D and J. H. Torrie. 1992. Principle and procedure statistics 2 nd Ed. McGraw-Hill Book Co., Inc, Singapore.

Supriyati, T. Pasaribu, H. Hamid dan A. P. Sinurat. 1998. Fermentasi bungkil inti sawit secara substrat padat dengan menggunakan Aspergillus niger. Jurnal Ilmu Ternak dan Veteriner 3 (3): 165170. 